\title{
LAND ECOLOGICAL ENHANCEMENT, GREENSHIP NEIGHBORHOOD 1.0: A THEORETICAL AND CONCEPT STUDY INTO THE DESIGN FRAMEWORK OF A SUSTAINABLE BUILT ENVIRONMENT
}

\author{
Sarah Luziani ${ }^{1 *}$, Beta Paramita $^{1}$ \\ ${ }^{1}$ Department of Architecture, Faculty of Technology and Vocational Education, \\ Indonesian University of Education, Bandung 40154, Indonesia
}

(Received: July 2018 / Revised: August 2018 / Accepted: December 2018)

\begin{abstract}
Bandung is the third largest metropolitan city in Indonesia, and it has been recorded as having a "very low" Environmental Quality Index. In 2016, the mayor declared Perwal (Regulation of Mayor Bandung) No. 1023, which is related to green building and a sustainable built environment. The requirements are mandatory for buildings with a floor area of at least 5,000 $\mathrm{m}^{2}$. Meanwhile, Green Building Council Indonesia (GBCI) is a certification agency for green building, and the area has launched the Greenship Neighborhood (NH)/Region 1.0. This version is an assessment tool for disseminating and inspiring the application and realization of sustainable areas. Specifically, this paper aims to elaborate on the concept of NH 1.0 in the design framework, which can then be applied to a sustainable building plan. There are seven parameters of $\mathrm{NH} \mathrm{1.0,} \mathrm{but} \mathrm{this} \mathrm{study} \mathrm{only} \mathrm{focuses} \mathrm{on} \mathrm{the} \mathrm{application} \mathrm{of} \mathrm{the} \mathrm{"land} \mathrm{ecological}$ enhancement" (LEE) parameters. These parameters are intended to maintain the harmony and balance of environmental ecosystems and improve the quality of a healthy built environment. The description of LEE parameters includes the following: (1) basic green area; (2) green area for the public; (3) habitat conservation; (4) land revitalization; (5) microclimate; and (6) productive land. Teknopolis Gedebage, Bandung is chosen as the study area. This area is planned as the center of East Bandung as an integrated smart city, which is legalized by Perda Kota Bandung (Local Regulation) No. 2/2004. A specific discussion of LEE parameters is provided, which are then applied to the CBD (Central Business District) Gedebage as the preliminary design masterplan to determine the extent to which the LEE parameters can be applied to achieve a sustainable built environment. The design based on LEE parameters is also proven to be able to anticipate a decrease in the quality of the carrying capacity of the environment. The LEE parameters will broadly contribute to improving the Environmental Quality Index.
\end{abstract}

Keywords: Gedebage masterplan; Greenship neighborhood 1.0; Sustainable built environment

\section{INTRODUCTION}

Greater Bandung is the third largest metropolitan city in Indonesia. The population growth of Bandung, recorded as 0.37 p.a, makes a significant contribution to the physical development of the city (BPS Kota Bandung, 2016). Nevertheless, a non-integrated regional planning and design oriented to economic growth points to environmental degradation, which then contributes to several urban hazards. Kemen LHK RI (2016), launched its IKLH (Environmental

\footnotetext{
${ }^{*}$ Corresponding author's email: srhluziani@gmail.com, Tel. +62-82119018300, Fax.+62-22- 2013651 Permalink/DOI: https://doi.org/10.14716/ijtech.v9i7.2645
} 
Quality Index) in 2016. Indicators for assessing IKLH are based on the Air Pollution Index $(30 \%)$, Water Pollution Index (30\%), and Green Coverage Index (40\%). The score for normal IKLH is above 67, while the score for Bandung declined from 2011 to 2014, with results of $50.49,48.37,47.80$, and 45.06. This rating scale means that the region is in a state of alert. The lowest score in Bandung relates to green coverage. Air pollution conditions have also deteriorated from year to year, and the index decreased drastically, from 71.03 to 59.24. (Kemen LHK RI, 2016).

The Bandung government has established the RTRW (Bandung City Regional Spatial Plan) 2011-2031 (Pemkot Bandung, 2011), stated in the Regional Regulation of Bandung City No. 18 of 2011. There are two city service centers (PPKs): PPK Alun-alun and PPK Gedebage. Those PPKs must provide adequate infrastructure and facilities to serve the whole city and regional area. Thus, PPK Gedebage becomes our focus, since this area is the new extension of Eastern Bandung development and is mentioned in the Gedebage masterplan (Rencana Induk Kawasan Gedebage, RIKG). In principle, the planning of the Gedebage area aims to reduce the burden of activity and traffic in the center of Bandung, which has reached its maximum capacity. The Gedebage area was developed to reduce the burden of activity and traffic in the center of Bandung, which has also reached its maximum capacity. Commercial and service functions $(21.8 \%)$ occupy the third largest portion of the total area, after settlements $(27.6 \%)$ and infrastructure $(25.1 \%)$. RIKG has included the intensity of land use through the building coverage ratio (BCR), floor area ratio (FAR), and green coverage. RIKG has also provided guidance on flood control systems, drainage systems, and infiltration wells, while other planning provisions have not been regulated.

In the city of Bandung, there are already binding regulations related to buildings and sustainable areas, as outlined in Perwal (Mayor Regulation) No. 1023 of 2016. In the regulation, the construction must consider harmony with the building's environment in terms of social, cultural, and ecosystem elements. This requirement relates to buildings with a building floor area of at least $5000 \mathrm{~m}^{2}$ (Kemen PUPR RI, 2015). This Perwal intended to control the city development which is increasingly tend to explore the natural resources based on commercial demand basis neglecting the environmental aspects. The masterplan design, somehow has not been designed integrated with the aspects of ecological enhancement. By focuses on maintaining the harmony and balance of the environmental ecosystem, improving the quality of a healthy environment, and greatly minimizing the opening of new land. As a result, the land used can be efficient and maintain a natural balance.

Technology innovation plays a critical role in expediting transition to a sustainable mode of development and it becomes an important instrument to increase the flow of new ideas and next-generation products (Berawi, 2018). Thus, this study aims to explore the theoretical aspects of Greenship Neighborhood 1.0 (Greenship, 2015) as new innovation as benchmark tools, through LEE parameters. The synthesis of parameter later will be used as the design guidelines. To determine the rating/certification as a benchmark, the extent of the application of ecological enhancement criteria in this commercial area is used as a rating tool issued by the Green Building Council Indonesia (GBCI), and the benchmark tool is called Greenship.

\section{THE GREENSHIP RATING TOOLS}

GBCI is an emerging member of the World Green Building Council (WGBC) based in Toronto, Canada, which has more than 100 council institutions in over 80 countries. GBCI develops rating tools for green buildings called Greenships and certification activities on green buildings in Indonesia. Greenship, which has been issued by GBCI, comprises several types according to the object to be certified, as follows Greenship New Building (for new buildings), Greenship 
Existing Building (Greenship Interior Spaces), Greenship Neighborhood (for the region), and Greenship Home (for home building).

Greenship Neighborhood Version 1.0 is Greenship for the area, representing a valuation tool for disseminating and inspiring the application and realization of sustainable regional development. Sustainable development is development that seeks to meet the needs of the community without undermining the ability and sacrificing the needs of future generations (WCED, 1987).

Greenship is structured by involving building sector actors who are experts in their fields, such as architects, building industry workers, electrical mechanical technicians, interior designers, landscape architects, and others. It already has five types of benchmarks, namely for new buildings, existing buildings, interior spaces, homes, and neighborhood. It is further divided into six categories, consisting of appropriate site development (ASD), energy efficiency and conservation (EEC), water conservation (WAC), material, resource and cycle (MRC), indoor water health and comfort (IHC), and building and environment management (BEM). Rating categories for greenship neighborhood are shown in Table 1.

Table 1 Category of greenship neighborhood version 1.0

\begin{tabular}{clcc}
\hline No. & \multicolumn{1}{c}{ Category } & Score & Percentage \\
\hline 1. & Land Ecological Enhancement (LEE) & 19 & $15 \%$ \\
2. & Movement and Connectivity (MAC) & 26 & $21 \%$ \\
3. & Water Management and Conservation (WMC) & 18 & $15 \%$ \\
4. & Solid Waste and Material (SWM) & 16 & $13 \%$ \\
5. & Community Wellbeing Strategy (SWM) & 16 & $13 \%$ \\
6. & Building and Energy (BAE) & 18 & $15 \%$ \\
7. & Innovation and Future Development (IFD) & 11 & $9 \%$ \\
\hline \multicolumn{2}{c}{ Total } & 124 & $100 \%$ \\
\hline
\end{tabular}

The achievement and percentage of the value earned by a region in applying the various Greenship Neighborhood rating criteria will determine the rank of the certificate it can obtain. The assessment phase of Greenship is divided into two stages, as follows: design recognition (DR), with a maximum score of 77 points, and final assessment (FA), with a maximum value of 101 points. The rating of certificates issued by GBCI can be seen in Table 2 .

Table 2 Rank on greenship rating tools

\begin{tabular}{lccc}
\hline \multicolumn{1}{c}{ Rank } & Percentage & Score Min. DR & Score Min. FA $^{* *}$ \\
\hline Platinum & $73 \%$ & 56 & 74 \\
Gold & $57 \%$ & 43 & 58 \\
Silver & $46 \%$ & 35 & 46 \\
Bronze & $35 \%$ & 27 & 35 \\
\hline
\end{tabular}

Information: *DR: Design Recognition, ${ }^{* *}$ FA: Final Assessment

This study only discusses objective assessment results using the land ecological enhancement (LEE) category in Greenship Neighborhood Version 1.0. This category has seven points to rate. These are as follows: basic green area, green area for public, habitat conservation, land revitalization, microclimate, and productive land. 


\section{METHODS}

The quantitative process was carried out for calculating the amount of land per part of the Ruang Terbuka Hijau (RTH)/Green Open Space categories of paving block, building, rice field, and lake. Quantitative research is also widely employed for assessment using Greenship Neighborhood Version 1.0, where the rating tools are already available in tables for assessment.

Sustainability education has an important mission to fill this gap. Due the necessity of sustainability education and the necessity for originality of the method to be used in this education, school buildings are significant materials in education ( $\left.\operatorname{Tasc}_{1}, 2015\right)$.

The research was conducted by carrying out a literature study to enrich the contents of the study. Then, the criteria calculation was done in an MS Excel worksheet because there were few data and the measurement was simple. Next, an analysis was performed from the results of the calculation to obtain a solution so that the calculation would provide the maximum results. Figure 1 explains the process design using the Greenship Neighborhood Version 1 rating tools.

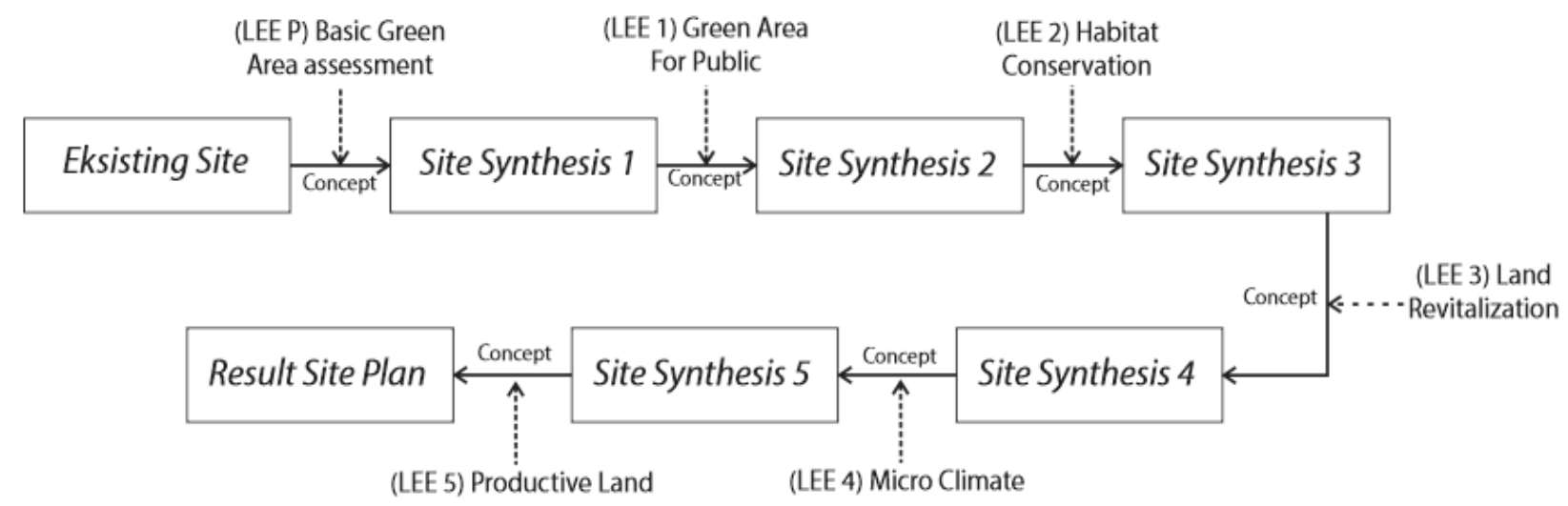

Figure 1 Matrix of the design process

\subsection{Design Synthesis}

The concept of the application of LEE from Greenship Neighborhood Version 1.0 can be broken down into basic green area, green area for the public, habitat conservation, land revitalization, microclimate, and productive land, as shown in Table 3.

Table 3 Process design for the masterplan CBD Gedebage

\begin{tabular}{|c|c|c|c|}
\hline No. & Parameters & Concept & Synthesis on Design \\
\hline LEE & Basic Green & According to the Regional Green Base & 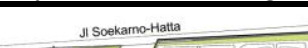 \\
\hline Primary & Area & $\begin{array}{l}\text { Coefficient, availability of green space is } 35 \% \text {, } \\
\text { and for the built land, it is } 50 \% \text { according to the } \\
\text { building coverage ratio (BCR). } \\
\text { Open green space is used as human interaction } \\
\text { with nature. }\end{array}$ & \\
\hline LEE 1 & $\begin{array}{l}\text { Green Area for } \\
\text { the Public }\end{array}$ & $\begin{array}{l}\text { Providing green open space for the public } \\
\text { representing at least } 25 \% \text { of the land area }\end{array}$ & \\
\hline
\end{tabular}




\begin{tabular}{|c|c|c|c|}
\hline No. & Parameters & Concept & Synthesis on Design \\
\hline LEE 2 & $\begin{array}{c}\text { Habitat } \\
\text { Conservation }\end{array}$ & $\begin{array}{l}\text { Maintaining more than } 60 \% \text { native plants and } \\
\text { maintain Kuntul Kerbau (Group of bird) habitat. }\end{array}$ & \\
\hline LEE 3 & $\begin{array}{l}\text { Land } \\
\text { Revitalization }\end{array}$ & $\begin{array}{l}\text { Minimum percentage of } 50 \% \text { of the revitalized } \\
\text { land area }\end{array}$ & \\
\hline LEE 4 & Micro-climate & $\begin{array}{l}\text { Improve the microclimate by as much as } 80 \% \text { by } \\
\text { increasing the vegetation with leaf area intensity } \\
\text { (LAI) within } 2-4 \mathrm{~m} \text {. }\end{array}$ & \\
\hline LEE 5 & $\begin{array}{l}\text { Productive } \\
\text { Land }\end{array}$ & $\begin{array}{l}\text { Own separate land to produce vegetables and } \\
\text { fruit to meet community needs. There are some } \\
\text { rice fields from existing sites. }\end{array}$ & \\
\hline
\end{tabular}

\section{RESULTS AND DISCUSSION}

\subsection{General Review}

The CBD project is planned for the next Gedebage Integrated Area to be a Teknopolis Region, with the coordinate points of $-6.9373811,107.6949433,17$, Jl. Soekarno Hatta No. 735, Cimenerang, Gedebage, Bandung City. This area is about $400.231 \mathrm{~m}^{2}$ and is covered predominantly by rice fields.

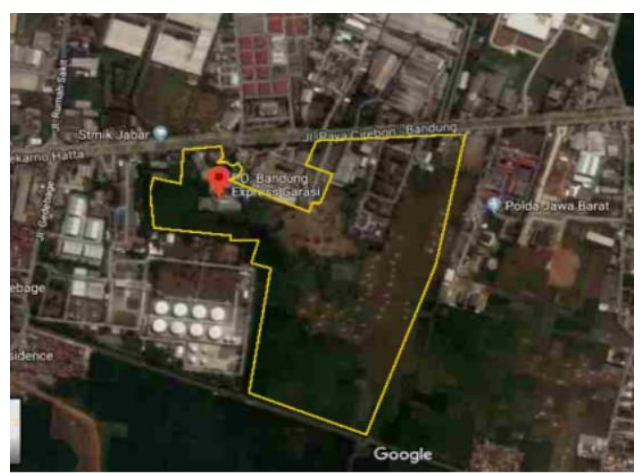

Figure 2 Land location to be built 
The area will be planned to have residential, office, hotel, shopping, and entertainment functions. Each land function will be connected with through flyover for vehicles and sky bridge for pedestrians. The main program designed in this CBD is urban farming, where the existing rice fields would be preserved (displaced), which means that the farmers who are natives of Gedebage will not lose their livelihoods, and instead, they will mingle with the residents of CBD, who are mostly immigrants.

\subsection{Greenship Neighborhood 1.0 Assessment}

The assessment of Greenship Neighborhood Version 1.0 on the Preliminary Gedebage Central Business District Category of Land Ecological Enhancement as seen at Figure 3. This masterplan shows that green open space occupies the largest area as much as $50.8 \%$, where paving as the connection only covered $1.6 \%$. In the basic green area category, there are the requirements delineated in the next subsections.
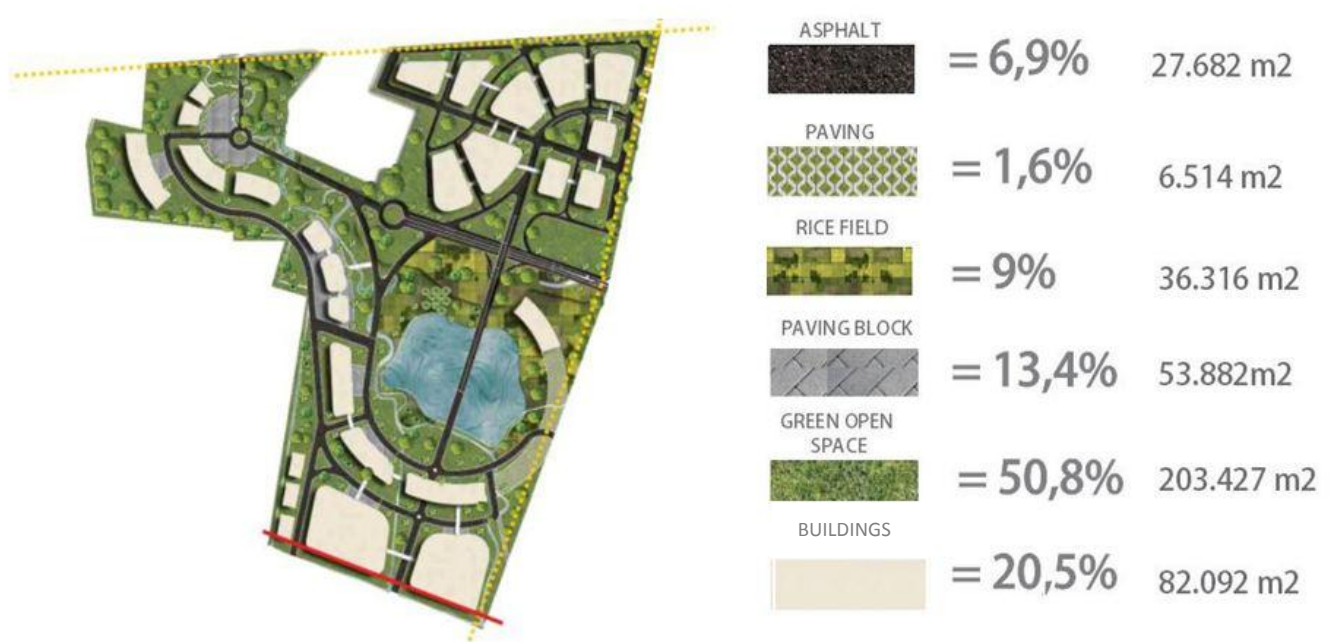

Figure 3 Preliminary masterplan for Gedebage CBD and some information about land use

\subsubsection{Basic green area}

The objectives to be achieved for this point are maintaining the harmony and balance of the ecosystem environment, as well as improving the quality of a healthy environment. In the CBD planned to meet the harmony and balance of the ecosystem environment. The aim is to preserve the existing land in the form of rice fields, representing as much as $50.8 \%$ of the total land or $203,427 \mathrm{~m}^{2}$. For this category, CBD Gedebage meets or is worth P points. The adoption of 'environmentally-aware' building designs, the application of alternative and/or recycled/environmentally-friendly materials, a number of "green" technologies and building systems featured in this building concept deliver more value without jeopardizing the ecology. (Firmawan, et.al, 2012)

\subsubsection{Green area for the public}

The goals to be achieved at this point are improving the quality of the environment and public health, as well as encouraging interaction by providing open space. At this point, the goal has been fulfilled because there is public space accounting for at least $25 \%$ of the land area. It has been calculated that $64.2 \%$ of green land is open to the public, where $50.8 \%$ is non-pavement land and $13.4 \%$ is block pavement. This is already fulfilled because CBD Gedebage owns $64.2 \%$ of the open green land for the public, so it receives 4 points.

\subsubsection{Habitat Conservation}

The goal to be achieved at this point is to minimize development's effects on the balance and biodiversity of natural species. This is because there are few large trees in the area, and it is 
dominated by rice fields. This CBD retains most of the existing rice fields and preserves the heron bird species. On the banks of the river in the existing area is a conservation area for these birds. At this point, CBD Gedebage has met the requirements, so it receives 6 points.

\subsubsection{Land revitalization}

The objective to be achieved for land revitalization is to avoid development in the greenfield area and the opening of new land. However, based on a land suitability study conducted by the Directorate of Environmental Governance in the Gedebage region, the geological makeup is described as loamy clay, a peat layer, sand, and sandy clay. This land is basically a swamp and the type of soil that is scattered in this region mostly alluvial soil.

At this point, the Gedebage CBD area has cleared new land in the green open space, which is mostly dominated by rice fields. Thus, the CBD Gedebage does not meet the Greenship

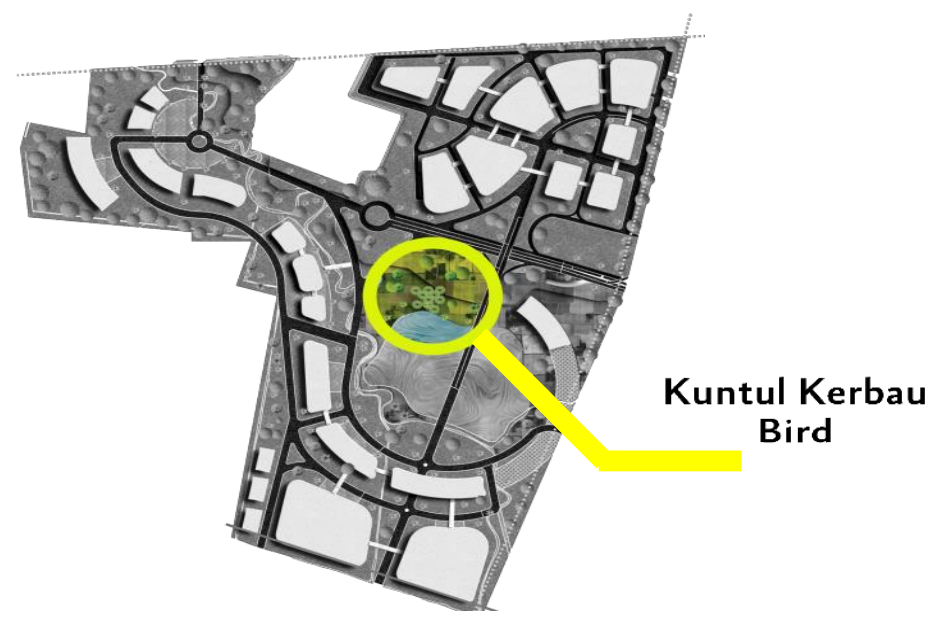

Neighborhood Ver. 1.0 standard for land revitalization.

Figure 4 Location of Kuntul Kerbau bird conservation

\subsubsection{Micro-climate}

The goal to be achieved at this point is to improve the quality of the microclimate around the area and reduce urban heat islands (UHIs). The concept suggests the greenery to cover $80 \%$ of area. This plan is in accordance with the results of the research that greeneryhave the potential to manipulate the sun and wind to improve the microclimate surrounding the buildings (Paramita \& Fukuda, 2014).

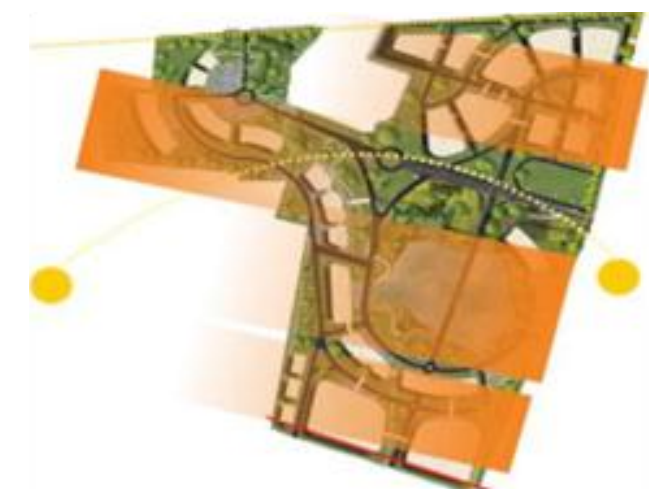

Figure 5 Areas most likely to be exposed to sunlight are colored orange

In Figure 5, areas most likely to be exposed to sunlight are colored orange to analyze shading 
and the location of vegetation).

The tree vegetation structure is effective for reducing air temperature. The tree vegetation structure with a round crown and denser branching pattern, with a height of medium trees of 6$10 \mathrm{~m}$ and shading function, has proven to be more effective for increasing the comfort in the surrounding area (Sanger, 2016).

From the optimization simulation conducted, the vegetation design improves thermal comfort, as determined by the decrease in the area's temperature of $0.32-1.16^{\circ} \mathrm{C}$ in the corridor; in contrast, with vegetation, especially the type of humidity, humidity is increased by $0.12-3.84 \%$. Vegetation can reflect, absorb, and transmit the solar radiation used in the internal biological process; moreover, it is capable of reducing solar radiation to the corridor surface and decreasing the MRT value by $0.10-36.68^{\circ} \mathrm{C}$.

Technically, planting will be distinguished between two tiers of trees. Trees numbered 1 in Figure 6 are medium-high, at 10-15 m, and those numbered 2 are smaller, with a height of $<10$ $\mathrm{m}$. The small one is planted on the yard as a separator between the private and public zones.

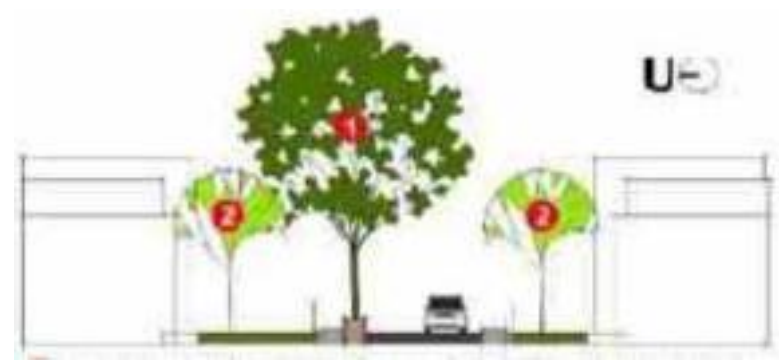

Figure 6 Example of the size of canopy to be planted in the CBD Gedebage area

The trees will be spread over the entire green area, or about $50.8 \%$ of the total land. This already meets a minimum percentage of $40 \%$, which is worth 1 point, while $60 \%$ is worth 2 points and $80 \%$ is worth 3 points. CBD Gedebage has fulfilled more than $40 \%$ to receive 1 point. Trees with wide crowns should be planted throughout the CBD area, and it is desired for $30 \%$ of the total area to be covered by tree canopy.

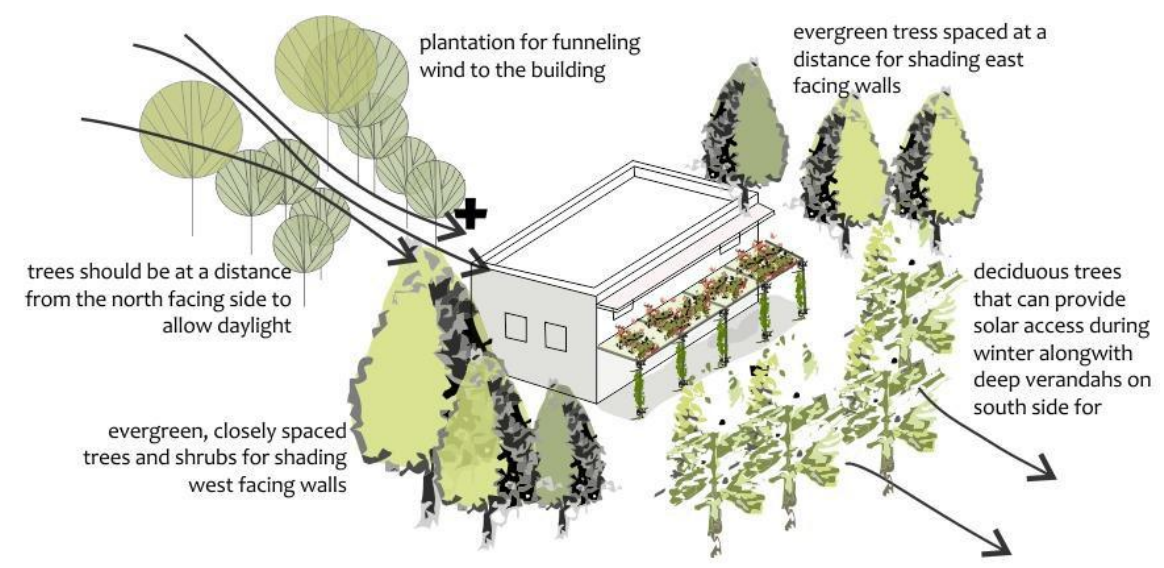

Figure 7 Trees for altering the microclimate

(Source: http://www.nzeb.in/knowledge-centre/passive-design/vegetation/)

\subsubsection{Productive land}

The objectives to be achieved at this point are to encourage local food production and reduce the carbon footprint stemming from food transport emissions. CBD Gedebage is designed to minimize building over the rice field area, and the total area of rice fields remaining in the CBD 
Gedebage area is $15 \%\left(36.316 \mathrm{~m}^{2}\right)$ of the $59.8 \%$ of the total green open space available in this area (see Figure 2). This is beneficial for the citizens who are natives of Gedebage. Their livelihood has not been lost, and they will become even more productive because their products will be consumed by many resident immigrants in this CBD Gedebage. This has met the criteria of Greenship Neighborhood, where obtaining 2 points requires an effective local food production area of more than $10 \%$ of green open space.

The idea of land revitalization can be done by optimizing the building area (roof and wall). Green roof system or vertical garden for urban farming with the concept of hydroponics. The extensification through urban farming is absolutely necessary, since previously this area covers 500 ha of agricultural land.

\subsection{Results}

In general, the results of the Greenship Neighborhood Version 1.0 assessment on the preliminary design of the CBD Gedebage masterplan are presented in Table 4.

Table 4 Greenship neighborhood ver. 1.0 assessment

\begin{tabular}{clcc}
\hline No. & \multicolumn{1}{c}{ Category } & Max. Score & Score \\
\hline 1 & Basic Green Area & Primary & Primary \\
2 & Green Area for the Public & 4 & 4 \\
3 & Habitat Conservation & 6 & 6 \\
4 & Land Revitalization & 4 & 1 \\
5 & Microclimate & 3 & 1 \\
6 & Productive Land & 2 & 2 \\
\hline & Total & 19 & 14 \\
\hline & Total Percentage & $100 \%$ & $73 \%$ \\
\hline
\end{tabular}

From the results of these measurements, it is known that the CBD Gedebage masterplan has been good and classified as reaching $73 \%$ Platinum points in general. The basic green area category has obtained as Primary $(\mathrm{P})$ points, where the land already has more than $50 \%$ green open land. The green area for the public category has received 4 out of 4 points. The habitat conservation category has received 6 out of 6 points, where the CBD Gedebage masterplan has conserved native plant habitat and animal habitat for the buffalo herons. For land revitalization, it has obtained 1 out of 4 points; this represents a weakness in the CBD Gedebage masterplan, as CBD Gedebage is built on active land. In the microclimate category, 1 out of 3 points has been assigned because there are not many shade trees compared with the large land ratio. In the productive land category, 1 of 1 points has been obtained, as CBD Gedebage already has productive land to produce its own food.

\section{CONCLUSION}

The use of LEE - Greenship Neighborhood 1.0 as the theoretical to break down the concept and then applied to the design synthesis has proven beneficial to the sustainable built environment. The results of the design of the CBD Gedebage masterplan area were objectively assessed using the Greenship Neighborhood Version 1.0 rating with an LEE category score of 14 out of 19, representing a percentage of $73 \%$ out of $100 \%$. The LEE parameter emphasizing that the most important thing is to respond and appreciate the existing environment for ecosystem balance. From the assessment results, it is known that the preliminary design CBD Gedebage masterplan has already almost fully responded to the surrounding environment and existing land. The 
synthesis of a sustainability-based design approach is, to a minimum, change the existing ecosystem. If there is a change, extension must be made to the existing land/area so that its function can be replaced optimally.

\section{REFERENCES}

Badan Pusat Statistik Kota Bandung (BPS Kota Bandung), 2016. Kota Bandung Dalam Angka 2016 (City of Bandung in Figures 2016). The Central Bureau of Statistics of Bandung City, Indonesia

Berawi, M.A., 2018. Creating Sustainable Design and Technology Development: A Call for Innovation. International Journal of Technology. Volume 6(1), pp. 1-2

Firmawan, F., Othman, F., Yahya, K., 2012. Improving Project Performance and Waste Reduction in Construction Projects: A Case Study of a Government Institutional Building Project. International Journal of Technology, Volume 3(2), pp. 182-192

Greenship, 2015. Greenship Neighborhood Version 1.0. Green Building Council Indonesia, Indonesia

Kementerian Lingkungan Hidup dan Kehutanan Republik Indonesia (Kemen LHK RI), 2016. Indeks Kualitas Lingkungan Hidup Tahun (IKLH) (Environmental Quality Index), 2016. The Ministry of Environment and Forestry of the Republic of Indonesia, Jakarta, Indonesia

Kementerian Pekerjaan Umum dan Perumahan Rakyat Republik Indonesia (Kemen PUPR RI), 2015. Peraturan Menteri Pekerjaan Umum dan Perumahan Rakyat No. 02/PRT/M.2015 (Minister of Public Works and Public Housing Regulation No. 02/PRT/M.2015). The Ministry of Public Works and Public Housing of the Republic of Indonesia, Jakarta, Indonesia

Paramita, B., Fukuda, H., 2014. Heat Intensity of Urban Built Environment in Hot Humid Climate Region. American Journal of Environmental Sciences, Volume 10(3), pp. 210-218

Pemerintah Kota Bandung (Pemkot Bandung), 2011. Peraturan Daerah Kota Bandung No. 18 tahun 2011 Tentang Rencana Tata Ruang Wilayah Kota Bandung 2011-2031 (Regional Regulation of Bandung City No. 18 of 2011 Concerning the Bandung City Spatial Planning 2011-2031). The Governor of Bandung City, Bandung, Indonesia

Sanger, Y.Y.J., Rogi, J.E.X., Rombang, J., 2016. Pengaruh Tipe Tutupan Lahan Terhadap Iklim Mikro di Kota Bitung. Agri-SosioEkonomi Unsrat, Volume 12(3A), pp. 105-116

Tasc 1 , B.G., 2015. Sustainability Education by Sustainable School Design. Procedia - Social and Behavioral Sciences, Volume 186, pp. 868-873

World Commission on Environment and Development (WCED), 1987. Our Common Future. Oxford University Press, Oxford 